\title{
Cutaneous toxicities of targeted therapies in the treatment of hepatocellular carcinoma
}

\author{
Tarik Silk ${ }^{1}$, Jennifer $\mathbf{W u}^{2}$ \\ IInternal Medicine, New York University School of Medicine, New York, NY 10016, USA. \\ ${ }^{2}$ Hematology and Medical Oncology, Perlmutter Cancer Center, New York University School of Medicine, New York, NY 10016, \\ USA.
}

Correspondence to: Dr. Jennifer Wu, Hematology and Medical Oncology, Perlmutter Cancer Center, New York University School of Medicine, New York, NY 10016, USA. E-mail: jennifer.wu@nychhc.org

How to cite this article: Silk T, Wu J. Cutaneous toxicities of targeted therapies in the treatment of hepatocellular carcinoma. Hepatoma Res 2020;6:73. http://dx.doi.org/10.20517/2394-5079.2020.61

Received: 23 Jun 2020 First Decision: 5 Aug 2020 Revised: 30 Aug 2020 Accepted: 9 Sep 2020 Published: 16 Oct 2020

Academic Editor: Shu-Kui Qin Copy Editor: Cai-Hong Wang Production Editor: Jing Yu

\begin{abstract}
Liver cancer accounts for $4.7 \%$ of all newly diagnosed cancers and $8.2 \%$ of cancer deaths annu-ally. Hepatocellular carcinoma (HCC) accounts for the majority of primary liver cancers. There are 2 curative strategies in HCC: resection and transplant. Unfortunately, 50\% of patients who undergo resection will relapse in 2 years and many patients on transplant lists become ineligible for transplant due to disease progression. The majority of patients still require systemic therapies. Tyrosine kinase inhibitors have successfully extended the overall survival in patients with hepa-tocellular carcinoma. However, these treatments have been noted to cause severe side effects in-cluding liver toxicity, hypertension, gastrointestinal toxicity and cutaneous adverse effects. This article will focus on the adverse skin reactions seen during the treatment of hepatocellular carci-noma by various tyrosine kinase inhibitors. The focus will be symptomatology, management, and whether the development of cutaneous toxicities can be prognostic.
\end{abstract}

Keywords: Hepatocellular cancer, tyrosine kinase inhibitors, cutaneous toxicity, hand foot reaction syndrome

\section{BACKGROUND}

Liver cancer accounts for $4.7 \%$ of all newly diagnosed cancers and $8.2 \%$ of cancer deaths annually ${ }^{[1]}$. Hepatocellular carcinoma (HCC) accounts for the majority of primary liver cancers ${ }^{[2]}$. As much as $50 \%$ of patients with HCC are diagnosed at early stages when curative treatments are possible ${ }^{[3]}$. There are

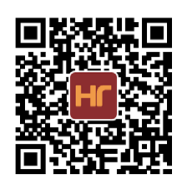


2 curative strategies in HCC: resection and transplant. Unfortunately, 50\% of patients who undergo resection will relapse in 2 years and many patients on transplant lists become ineligible for transplant due to disease progression. The majority of patients still require systemic therapies. In 2008, the FDA approved the tyrosine kinase inhibitor (TKI) Sorafenib as the first systemic therapy for patients with inoperable hepatocellular cancer. Its approval was based on the overall survival (OS) benefit of Sorafenib compared to placebo in the first-line setting 10.7 months vs. 7.9 months, respectively ${ }^{[4]}$. Since Sorafenib's approval, several other tyrosine kinase inhibitors have been added to the armamentarium against late-stage HCC. These new TKIs include Lenvatinib, Cabozantinib, and Regorafenib ${ }^{[5-7]}$. Cutaneous toxicities are frequently observed during targeted treatment of cancer, as many targeted therapies, including TKIs, inhibit growth factors found in the $\operatorname{skin}^{[8]}$.

In this review, we will focus on the adverse skin reactions seen during the treatment of hepatocellular carcinoma by various tyrosine kinase inhibitors. The focus will be on symptomatology and management of these reactions. Additionally, this review will discuss whether the development of cutaneous toxicities can be prognostic.

Symptomatology and treatment for particular cutaneous toxicities are discussed with each major toxicity. The cutaneous toxicities of particular TKIs will be discussed within each TKI's section along with the toxicity's onset and suggested dose modifications of the TKI.

\section{HAND FOOT REACTION SYNDROME}

\section{Risk factors and incidence}

The incidence of hand foot reaction syndrome (HFRS) in the treatment of HCC varies depending on the TKI $^{[9]}$. Predisposing factors to HFRS seen in TKI treatments include female gender, ECOG status 2 or lower, two or more organs involved, baseline lung/liver metastases, a baseline white blood count above $5.5 \times 10^{9} \mathrm{cells} / \mathrm{L}$, and the duration of the TKI therapy ${ }^{[10]}$. Frequency is also higher in Asian populations ${ }^{[11,12]}$. Whereas incidences of HFRS are varied, symptomatology of HFRS is shared between TKIs.

\section{Symptoms}

Patients affected by HFRS experience a prodromal tingling sensation on their palms or soles which progresses to burning pain. Hand and foot erythema and edema develops with tense blistering and peeling with lesions evolving into areas of callus-like hyperkeratosis with surrounding erythema ${ }^{[13-16]}$.

Lesions tend to develop over pressure-bearing surfaces, which may be related to the pathophysiology of their development.

\section{Pathophysiology}

Although competing hypotheses exist ${ }^{[9,17,18]}$, the TKI dual inhibition of different receptors, such as VEGF and PDGFR, may be required to trigger dermatological symptoms. Damage occurs when TKIs block signaling pathways resulting in the alteration of repair mechanisms or distortion to microvascular structure in areas where there is frequent trauma or friction like the palms and soles ${ }^{[12,14,18]}$.

\section{Toxicity grading and treatment}

Management of HFRS is based on expert knowledge from oncologists and dermatologists. Before TKI treatment begins, proper consultation with podiatry and dermatology should be made. A full-body skin examination with special attention paid to the hands and feet should be performed. Evidence of abnormal weight bearing can be corrected with mechanical support. Areas of baseline hyperkeratotic skin can be removed with manicures and pedicures ${ }^{[19,20]}$. During treatment, twice daily prophylactic application of a $20 \%$ urea-based cream has also been suggested by some experts to prevent HFRS ${ }^{[20,21]}$. When treatment 
is started patients should be advised to avoid tight footwear or gloves. Patients should protect their feet with insole cushions, shock-absorbing soles, and padded socks and wear gloves to protect their hands. Emollients can be used liberally.

At night, patients should continue to wear cotton gloves and socks to retain moisture. They should also avoid extreme temperatures and wash with tepid water ${ }^{[14,15,18,20,22]}$.

Further recommendations are based upon the grade of HFRS severity. The toxicity grading of HFRS is characterized according to the National Cancer Institute. Grade 1 toxicity is characterized by minimal skin changes or dermatitis (i.e., edema, redness, or hyperkeratosis) but without pain. Grade 2 toxicity develops with skin changes (i.e., peeling, blisters, bleeding, fissures, edema, or hyperkeratosis) with pain and limits daily activities. Grade 3 toxicity is marked by severe skin changes (i.e., peeling, blisters, bleeding, fissures, edema, or hyperkeratosis) with pain that limits self-care ${ }^{[23]}$.

Grade 1 toxicities can be managed with topical therapy usually with the continuation of the TKI dose $\mathrm{e}^{[19,20,22]}$. Topical treatments are similar to those used for prophylactic care. $20 \%-40 \%$ urea creams should be used on areas of hyperkeratosis twice a day ${ }^{[15,18,20,22]}$.

Grade 2 toxicities are managed with topical therapy and dose reductions if necessary. Areas of hyperkeratosis should be treated with urea base keratolytic ${ }^{[16]} \cdot 0.05 \%$ Clobetasol ointment should be applied to erythematous areas twice daily ${ }^{[15,20,22]}$. Topical $2 \%$ lidocaine cream can be used for analgesia ${ }^{[20,22]}$.

For Grade 3 toxicities in addition to the above treatments, dose interruption and reduction is required. Other strategies include the use of pyridoxine with doses of $50-150 \mathrm{mg} /$ day $^{[20,22,24]}$.

Of note, in one uncontrolled study of 12 patients who developed HFRS when taking Sorafenib, the majority of patients that were treated twice daily with $40 \%$ urea cream in combination with tazarotene $0.1 \%$ cream or fluorouracil $5 \%$ cream saw a $\geq 2$-grade improvement in symptoms ${ }^{[25]}$ [Figure 1].

\section{RASH}

\section{Symptoms}

Rashes observed with TKI treatment vary and can develop as a macule, papule, maculopapular, erythematous, and/or pruritic. Rashes often develop on the trunk and extremities or scrotum ${ }^{[15,26-28]}$. Facial and scalp erythema similar to seborrheic dermatitis has been noted with Sorafenib.

\section{Treatment}

The treatment of rashes seen during TKI therapy is once again based upon the toxicity grade. Grade 1 toxicity is described as macules/papules covering $<10 \%$ body surface area (BSA) with or without symptoms (e.g., pruritus, burning, tightness). Grade 2 toxicity is characterized by macules/papules covering 10\%-30\% BSA with or without symptoms (e.g., pruritus, burning, tightness); limiting instrumental activities of daily living (ADL), or a rash covering > 30\% BSA with or without mild symptoms. Grade 3 toxicity is defined by macules/papules covering $>30 \%$ BSA with moderate or severe symptoms; limiting self-care $\mathrm{ADL}^{[23]}$.

In general, patients with rashes should be advised to use perfume-free soaps, apply moisturizers, and wear loose comfortable clothing ${ }^{[22,29]}$. Topical corticosteroids and antihistamines may also be useful with mild rashes ${ }^{[22,30]}$. Dose reductions and interruptions of the TKI should also occur based on prescribing information for severe rashes. With proper management, most rashes have been noted to resolve in less than 6 weeks $^{[27]}$. Additionally, some rashes may resolve spontaneously without symptomatic treatment as can be seen in patients with facial and scalp erythema ${ }^{[26,27]}$ [Figure 2]. 

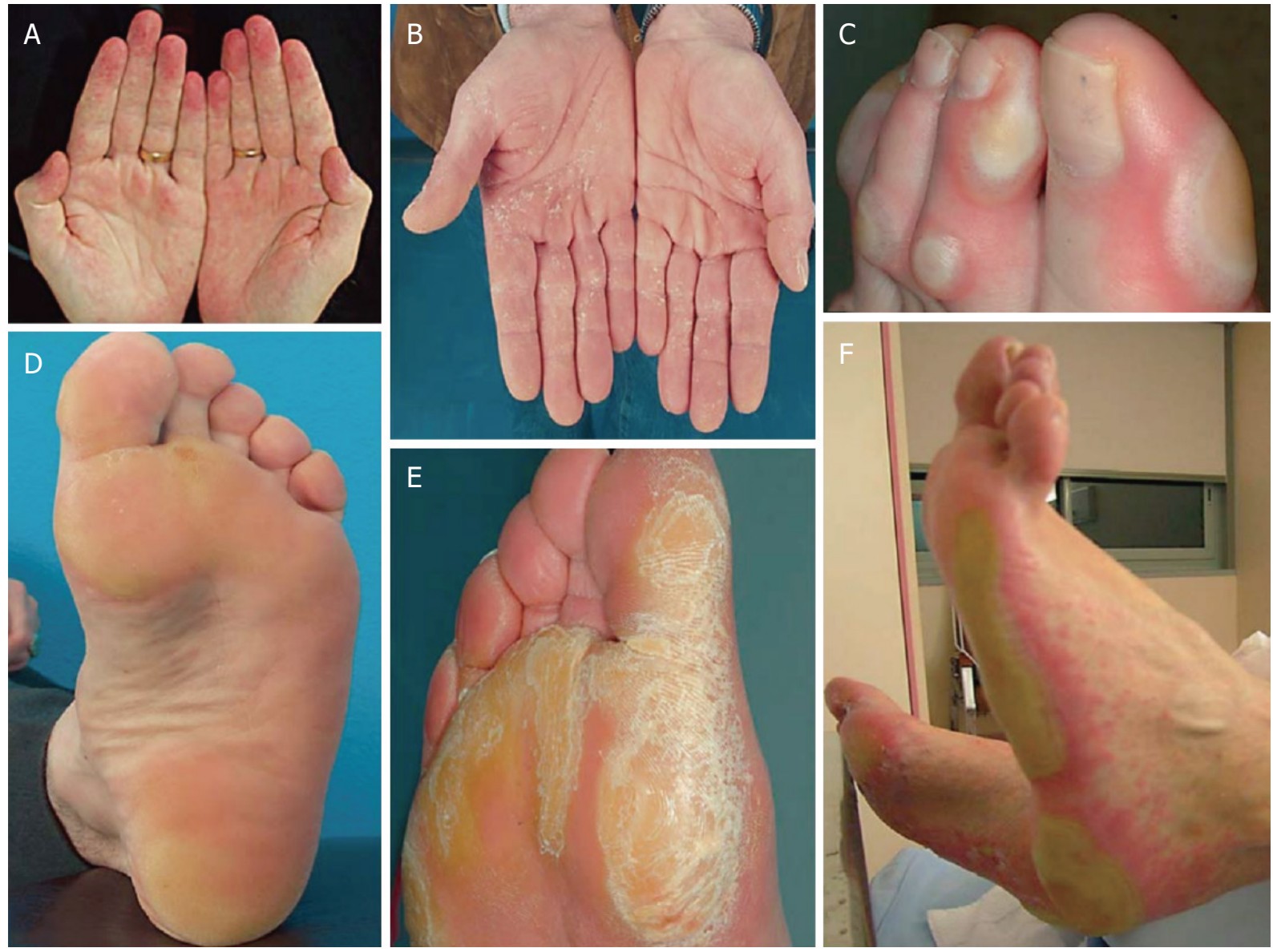

Figure 1. Clinical spectrum of HFRS of grade $1(A, D)$ grade $2(B, E)$ and grade $3(C, F)$. Used with permission from Lipworth et al. ${ }^{[13]}$, Copyright (C) 2009 Karger Publishers, Basel, Switzerland. HFRS: hand foot reaction syndrome

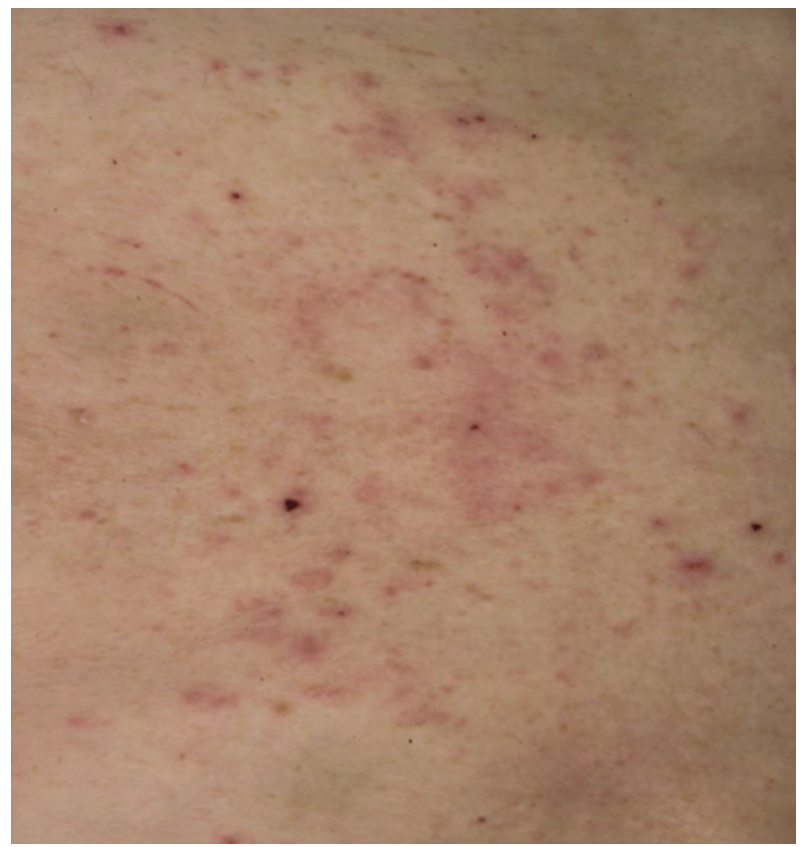

Figure 2. Example of rash on the trunk with TKI treatment. Used with permission under the Creative Commons Attribution License. (http:// creativecommons.org/licenses/by/2.0 $)^{[31]}$. TKl: tyrosine kinase inhibitor 


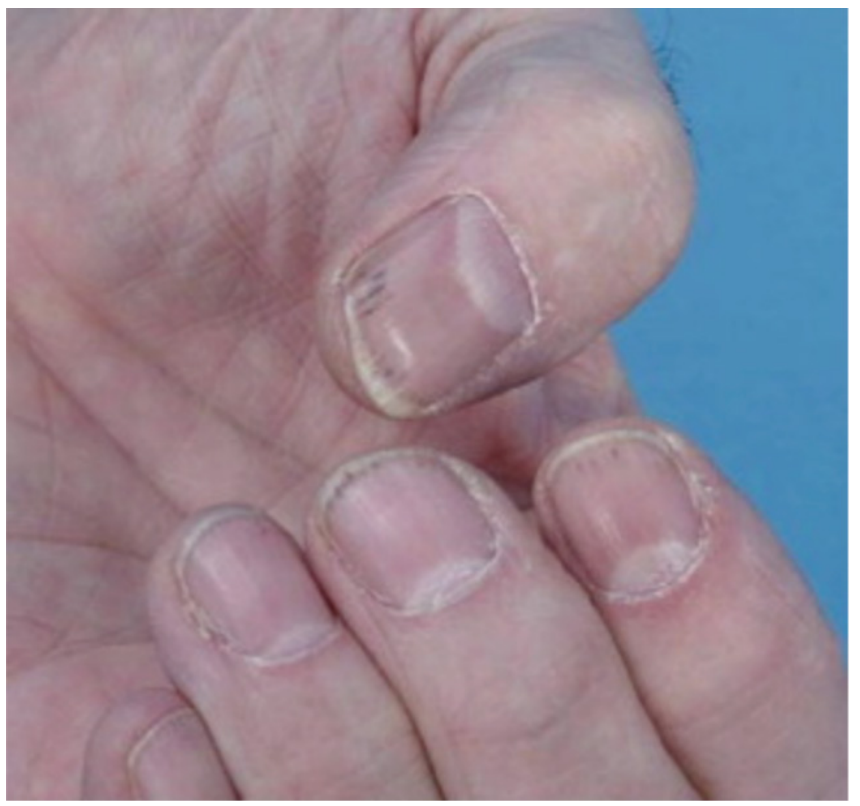

Figure 3. Subungual splinter hemorrhages in a patient on Sorafenib. Reprinted from Ishak et al. ${ }^{[33]}$

\section{SCROTAL ECZEMA}

\section{Symptoms}

Scrotal eczema appears as erythematous macules ${ }^{[32]}$.

\section{Treatment}

Scrotal lesions seen with TKIs have been treated with athletic supporters to reduce friction and barrier ointments/pastes such as zinc oxide and menthol. Topical steroids can also be used ${ }^{[1,32]}$.

\section{SUBUNGUAL SPLINTER HEMORRHAGES}

\section{Symptoms}

Subungual splinter hemorrhages appear as multiple subcentimeter longitudinal brown to black lines beneath the distal nail plate. They are asymptomatic ${ }^{[26]}$.

\section{Treatment}

Subungual splinter hemorrhages do not require treatment as they tend to spontaneously resolve ${ }^{[15,26,27]}$ [Figure 3].

\section{ALOPECIA}

\section{Symptoms}

Alopecia may occur with thinning or patchy hair loss. Complete alopecia has been seen in patients with renal cell carcinoma treated with Sorafenib. Alopecia can involve loss of hair on the body as well as the scalp $^{[26]}$.

\section{Treatment}

Alopecia produced by TKIs although distressing to patients has not been shown to require dose modification. Alopecia has spontaneously resolved in some patients despite continued treatment ${ }^{[26]}$. 


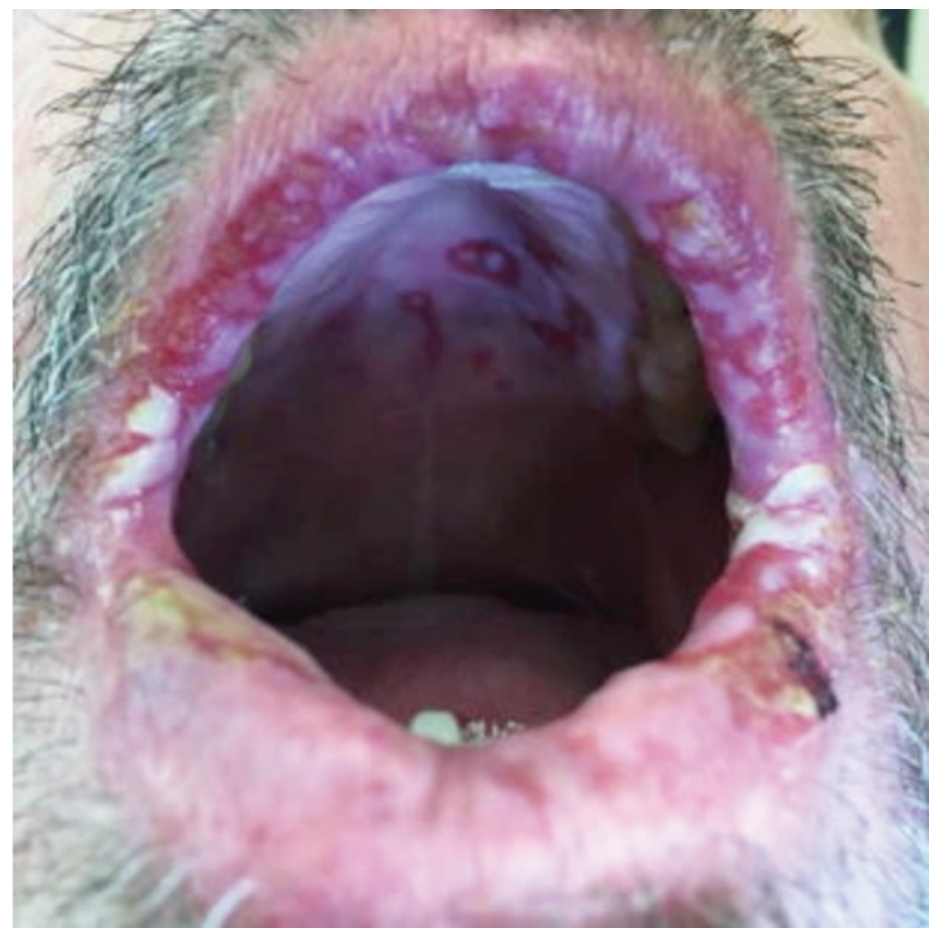

Figure 4. Example of stomatitis seen with TKI treatment. Used with permission under Creative Commons Attribution 4.0 International License (https://creativecommons.org/licenses/by/4.0) ${ }^{[39]}$. TKI: tyrosine kinase inhibitor

\section{STOMATITIS}

\section{Symptoms}

Stomatitis or oral mucositis may manifest as dry mouth, oral sensitivity, dysphagia, or taste changes ${ }^{[29,34]}$. Ulcers may also occur ${ }^{[22]}$.

\section{Toxicity grading and treatment}

Like HFRS, prevention may be the best strategy. Prophylactic measures include good oral hygiene by brushing teeth with a soft-headed toothbrush and fluoride toothpaste after meals and before sleep. Flossing once a day and using alcohol-free mouth rinses four times daily is encouraged. Dentures should be cleaned daily. Patients need to avoid spicy and sticky foods, as well as alcohol and tobacco ${ }^{[29,34,35]}$.

Further recommendations are based upon the grade of stomatitis severity. Adverse events of stomatitis are characterized according to the National Cancer Institute. Grade 1 toxicities are described as asymptomatic or mild symptoms. Grade 2 toxicities are characterized by moderate pain or ulcers that do not interfere with oral intake. Grade 3 toxicities involve severe pain interfering with oral intake ${ }^{[23]}$.

When adverse events do occur, grade $1 / 2$ events can be managed with magic mouthwash or swish spit rinses with $0.9 \%$ sodium bicarbonate or $0.9 \%$ saline- containing mouthwash ${ }^{[36,37]}$. Magic mouthwashes typically contain a mixture of diphenhydramine, viscous lidocaine, nystatin, dyclonine magnesium hydroxide, or aluminum hydroxide, and occasionally corticosteroids. However, bland saline rinses may be just as effective as magic mouthwashes ${ }^{[36]}$. Topical anesthetics, mucosal coating agents, and/or benzydamine $\mathrm{HCl}$ may be administered as needed for pain relief, but patients should be advised to avoid eating or performing oral hygiene when their mouth is numb. Grade 3 events require dose interruption and reduction $^{[22,34,38]}$ [Figure 4]. 


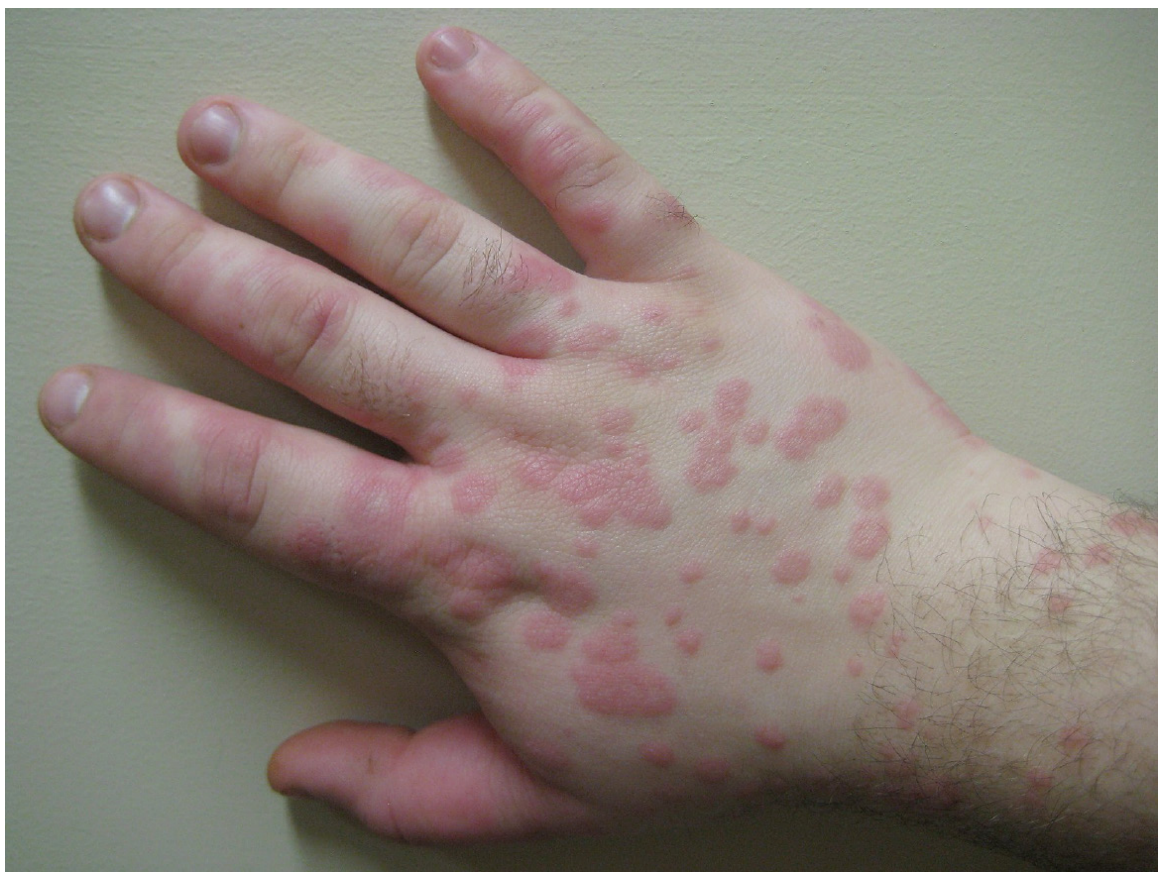

Figure 5. Example of erythema multiforme. Image author James Heilman, MD. Obtained under Creative Commons license AttributionShare Alike 3.0 Unported. https://creativecommons.org/licenses/by-sa/3.0/deed.en

\section{ERYTHEMA MULTIFORME}

\section{Symptoms}

Erythema Multiforme is typically a self-limited acute skin reaction that has been reported to occur within the first week of TKI treatment for $\mathrm{HCC}^{[40-42]}$. Lesions described in the case reports were targetoid erythematous lesions spread over the trunk and extremities. In one report, a patient developed painful oral lesions and, in general, oral lesions are found in up to $60 \%$ of people with erythema multiforme ${ }^{[42,43]}$. Erythema multiforme is diagnosed clinically based on the patient's history and physical examination. It usually has fixed lesions for a minimum of 7 days.

\section{Treatment}

Treatment involves medication discontinuation. Additionally for mild disease oral antihistamines with or without topical steroids are prescribed ${ }^{[42,4]}$. If painful mucosal erosions are present, they can be treated with high potency topical corticosteroid gels and magic mouthwashes. If oral lesions prevent sufficient oral intake, studies have recommended systemic glucocorticoids, including prednisone 40-60 mg daily with dosage taper over 2-4 weeks ${ }^{[42,44]}$ [Figure 5].

\section{STEVENS-JOHNSON SYNDROME AND TOXIC EPIDERMAL NECROLYSIS}

\section{Symptoms}

Stevens-Johnson syndrome (SJS) and toxic epidermal necrolysis (TEN) have both been reported to occur in patients with HCC treated with TKIs ${ }^{[40,45]}$. These are both life-threatening reactions that usually begin 4-28 days after taking the offending medication. SJS and TEN are a spectrum of epidermal necrolysis with SJS occurring with less than $10 \%$ skin detachment and TEN when there is greater than $30 \%$. Anything in between is called SJS-TEN ${ }^{[46,47]}$. Flu-like symptoms usually precede cutaneous manifestations. Initial lesions are usually erythematous, irregularly shaped, and can first appear on the face, upper trunk, and proximal extremities. Necrotic lesions coalesce and slough off either spontaneously or with applied lateral pressure (as seen in Nikolsky's sign) revealing the red underlying dermis. 


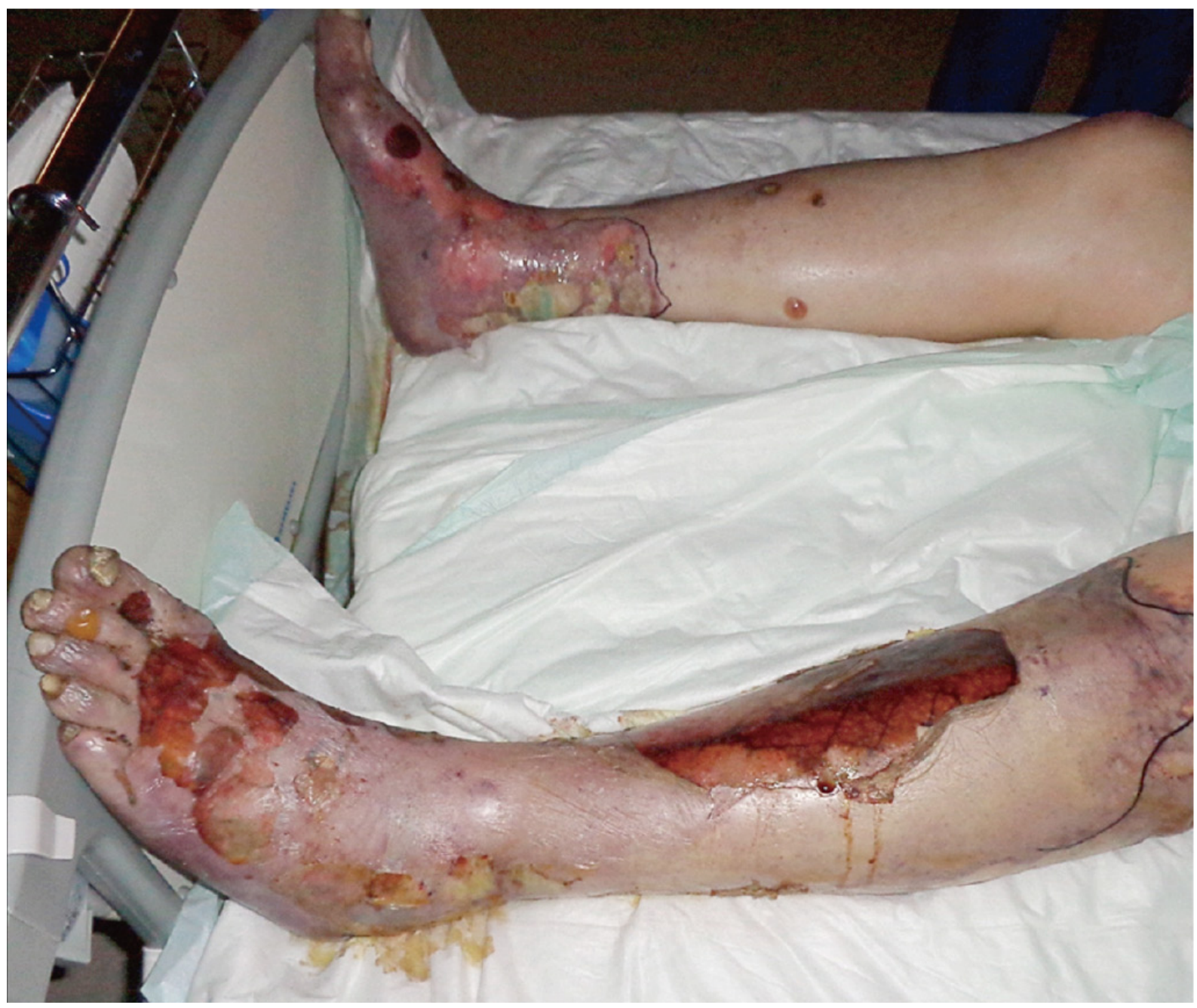

Figure 6. Example of Toxic Epidermal Necrolysis. Image author Afro Brazilian. Obtained with permission under Creative Commons license Attribution-Share Alike 3.0 Unported. https://creativecommons.org/licenses/by-sa/3.0/deed.en

\section{Treatment}

Treatment involves a multidiscipline approach. The TKI must be stopped and the patient should be transferred to the intensive care unit or burn unit. Supportive care measures involve thermoregulation with an ambient temperature of 28-32 degrees Celsius. If a respiratory compromise is suspected, these patients can be intubated. Administration of fluid replacement is advised at $0.7 \mathrm{~mL} / \mathrm{kg} /(\%$ affected area) along with a $5 \%$ albumin solution at $1 \mathrm{~mL} / \mathrm{kg} /(\% \text { affected area })^{[46,47]}$. Systemic corticosteroids are the most common treatment for SJS/TEN, a suggested protocol is intravenous dexamethasone at $1.5 \mathrm{mg} / \mathrm{kg}$ pulse therapy (given for 30-60 min) for 3 consecutive days ${ }^{[46,48]}$. Cyclosporine and Etanercept have also shown benefit ${ }^{[49,50]}$. Daily skin treatment is recommended with a daily antiseptic bath containing a solution of chlorhexidine 1/5000 or with a chlorhexidine spray. Skin debridement should be avoided because necrolytic sheets act as a natural biological dressing. Nonadhesive dressings are used to cover pressure points ${ }^{[4,50]}$ [Figure 6].

\section{TYROSINE KINASE INHIBITORS USED FOR HCC TREATMENT}

Tyrosine kinase inhibitors, including Sorafenib, Lenvatinib, Cabozantinib, and Regorafenib are small molecules that attack cancers by inhibiting the activity of receptor tyrosine kinases which are responsible for tumor-promoting pathways such as proliferation and angiogenesis ${ }^{[51]}$. 


\section{SORAFENIB}

\section{Sorafenib cutaneous toxicities and toxicity incidence}

Sorafenib was FDA approved for the treatment of HCC in 2008 after a phase three randomized placebocontrolled trial showed that it extended patient survival. Safety results of that study reported that $80 \%$ of patients taking Sorafenib experienced an adverse event with the majority of patients experiencing grade 1 or 2 dermatological events. These events and the percentage of patients reporting them included: alopecia (14\%, grade 3: $0 \%)$, dry skin (8\%, grade 3: $0 \%)$, HFRS (24\%, grade 3: $8 \%$ ), pruritus ( $8 \%$, grade 3: $0 \%)$, rash and/or desquamation $(16 \% \text {, grade } 3: 1 \%)^{[4]}$. Similar adverse events were also seen in another study that investigated Sorafenib therapy in an Asian-Pacific population ${ }^{[11]}$. Other cutaneous toxicities reported with Sorafenib include sublingual splinter hemorrhage which occurs in as many as $60 \%-70 \%$ of patients as well as case reports of scrotal eczema ${ }^{[32,52]}$.

\section{The onset of cutaneous toxicity with Sorafenib}

HFRS occurs within days or months after starting Sorafenib, but most commonly manifests during the first 6 weeks of therapy ${ }^{[22,26,27]}$. Rashes usually present on the extremities and/or the trunk within the first to the second month of treatment ${ }^{[22]}$. Scrotal rashes have been seen between the 2nd and 12 th weeks of therapy ${ }^{[22,27]}$. Alopecia observed in patients treated with Sorafenib occurs within four months of treatment ${ }^{[26,27]}$. The subungual splinter hemorrhages appear within the first 2 months of treatment ${ }^{[26,27]}$.

It is recommended that physicians see their patients in 2-week intervals for the first 2 months of Sorafenib treatment to manage skin toxicities ${ }^{[20,22]}$.

\section{Dose reductions}

The starting dose of Sorafenib is $800 \mathrm{mg}$ daily. Dose reductions for skin toxicity are seen in Tables 1,2 , and $3^{[38]}$.

\section{LENVATINIB}

\section{Lenvatinib cutaneous toxicity and toxicity incidence}

In a phase 3 trial, Lenvatinib was shown to be non-inferior to Sorafenib for OS in the first-line treatment of HCC that was not amenable to curative or local therapy ${ }^{[13]}$. Cutaneous toxicities seen with Lenvatinib include: HFRS (27\%, grade 3: $3 \%$ ), alopecia (3\% grade 3: $0 \%$ ) and rash $(10 \% \text {, grade } 3: 0 \%)^{[7]}$.

\section{The onset of cutaneous toxicity with Lenvatinib}

The onset of Lenvatinib's cutaneous toxicities for the treatment of HCC has not been described. However, their onset has been documented during the use of Lenvatinib for thyroid cancer ${ }^{[28]}$. The median time to the first onset of HFSR was 5.9 weeks and 7.3 weeks for rash. Most rashes occurred during the first cycle of therapy. Whereas HFRS could occur throughout therapy.

\section{Dose reductions}

Lenvatinib for HCC is dosed depending on body weight with patients $60 \mathrm{~kg}$ or greater started at $12 \mathrm{mg}$ daily whereas those less than $60 \mathrm{~kg}$ starting at $8 \mathrm{mg}$ daily. Dose reductions for skin toxicities are displayed in Tables 1,2 and $3^{[53]}$.

\section{CABOZANTINIB}

\section{Cabozantinib cutaneous toxicity and toxicity incidence}

Cabozantinib has been approved as second-line therapy for patients with HCC who have progressed on Sorafenib. In phase 3 CELESTIAL trial, Cabozantinib treated patients' median OS was 10.2 months (95\%CI: 9.1-12.0) compared to 8.0 months (95\%CI: 6.8-9.4) in patients treated with placebo. Cabozantinib cutaneous toxicities and incidences include: HFRS (46\%, grade 3: $17 \%$ ), stomatitis (13\%, grade 3: $2 \%$ ), and rash $(12 \% \text {, grade } 3<1 \%)^{[6]}$. 
Table 1. Hand foot reaction syndrome and tyrosine kinase inhibitor treatment modification

\begin{tabular}{|c|c|c|c|}
\hline \multirow{2}{*}{$\begin{array}{l}\text { Hand and Foot } \\
\text { Reaction Syndrome } \\
\text { Grade } \\
\end{array}$} & \multicolumn{3}{|c|}{ Tyrosine kinase inhibitor } \\
\hline & Sorafenib & Cabozantinib & Regorafenib \\
\hline $\begin{array}{l}\text { I: Minimal skin } \\
\text { changes or dermatitis } \\
\text { (i.e., edema, redness, } \\
\text { or hyperkeratosis) } \\
\text { without pain }\end{array}$ & No modification, use topical & relief agents & \\
\hline $\begin{array}{l}\text { II: skin changes } \\
\text { (i.e., peeling, } \\
\text { blisters, bleeding, } \\
\text { fissures, edema, or } \\
\text { hyperkeratosis) with } \\
\text { pain and limiting daily } \\
\text { activities }\end{array}$ & $\begin{array}{l}\text { 1st occurrence: Continue } \\
\text { treatment and consider } \\
\text { topical therapy for } \\
\text { symptomatic relief. If no } \\
\text { improvement within } 7 \text { days, } \\
\text { see below } \\
\text { No improvement, } 2 \text { nd or } \\
\text { 3rd occurrence: Interrupt } \\
\text { treatment until toxicity } \\
\text { resolves to Grade } 0 \text { - } 1 \text { When } \\
\text { resuming treatment, } \\
\text { decrease dose by one dose } \\
\text { level ( } 400 \text { mg daily or } 400 \\
\text { mg every other day) } \\
\text { 4th occurrence: Discontinue }\end{array}$ & 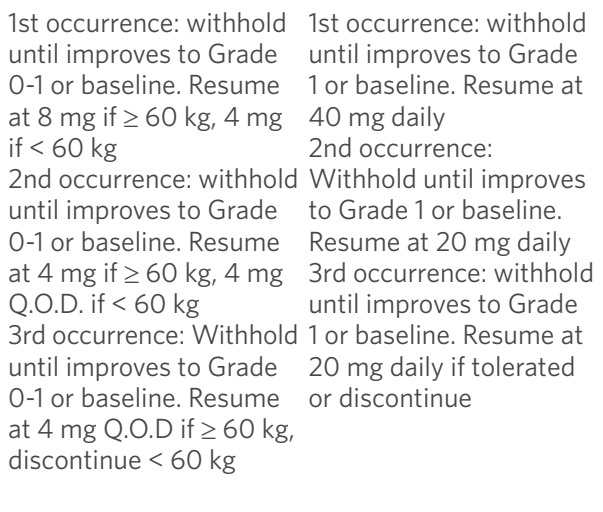 & $\begin{array}{l}\text { 1st occurence: Reduce dose } \\
\text { to } 120 \text { mg daily and start } \\
\text { supportive therapy. If the } \\
\text { toxicity does not improve } \\
\text { within } 7 \text { days interrupt therapy } \\
\text { until the toxicity resolves or } \\
\text { improves to grade } 1 \text {. Then can } \\
\text { restart at } 120 \text { mg daily } \\
\text { 2nd occurrence: Interrupt and } \\
\text { institute supportive measures } \\
\text { until toxicity resolves or } \\
\text { improves to grade } 1 \text {. Reduce } \\
\text { dose to } 80 \text { mg daily } \\
\text { 3rd occurrence: Discontinue if } \\
\text { failure to tolerate } 80 \text { mg daily } \\
\text { dose }\end{array}$ \\
\hline $\begin{array}{l}\text { III: Moist } \\
\text { desquamation, } \\
\text { ulceration, blistering, } \\
\text { or severe pain of the } \\
\text { hands or feet, resulting } \\
\text { in inability to work or } \\
\text { perform activities of } \\
\text { daily living }\end{array}$ & $\begin{array}{l}\text { 1st occurrence: Interrupt } \\
\text { treatment until toxicity } \\
\text { resolves to Grade } 0-1 \text {. } \\
\text { When resuming treatment, } \\
\text { decrease dose by one dose } \\
\text { level ( } 400 \text { mg daily or } 400 \\
\text { mg every other day) } \\
\text { 2nd occurrence: Interrupt } \\
\text { treatment until toxicity } \\
\text { resolves to Grade } 0-1 \text {. } \\
\text { When resuming treatment, } \\
\text { decrease dose by one dose } \\
\text { level ( } 400 \text { mg daily or } 400 \\
\text { mg every other day) } \\
\text { 3rd occurrence: Discontinue }\end{array}$ & Proceed the same as for grade II toxicity & $\begin{array}{l}\text { 1st occurrence: Interrupt } \\
\text { treatment and start supportive } \\
\text { measures. Treatment must } \\
\text { be interrupted until toxicity } \\
\text { resolves or improves to grade } \\
\text { 1. But treatment must be } \\
\text { stopped for a minimum of } 7 \\
\text { days. Resume dose at } 120 \text { mg } \\
\text { daily } \\
\text { 2nd occurrence: Interrupt } \\
\text { treatment and start supportive } \\
\text { measures. Treatment must } \\
\text { be interrupted until toxicity } \\
\text { resolves or improves to grade } \\
\text { 1. But treatment must be } \\
\text { stopped for a minimum of } 7 \\
\text { days. Resume dose at } 80 \text { mg } \\
\text { daily } \\
\text { 3rd occurrence: Discontinue }\end{array}$ \\
\hline
\end{tabular}

Table 2. Rash and tyrosine kinase inhibitor treatment modifications

\begin{tabular}{|c|c|c|c|c|}
\hline \multirow{2}{*}{$\begin{array}{l}\text { Rash } \\
\text { Grade }\end{array}$} & \multicolumn{4}{|c|}{ Tyrosine kinase inhibitor } \\
\hline & Sorafenib & Lenvatinib & Cabozantinib & Regorafenib \\
\hline $\begin{array}{l}\text { I: Macules/papules } \\
\text { covering }<10 \% \text { body } \\
\text { surface area (BSA) with } \\
\text { or without symptoms }\end{array}$ & No modification, use topica & al relief agents & & \\
\hline $\begin{array}{l}\text { II: Macules/papules } \\
\text { covering } 10 \text { - } 30 \% \\
\text { BSA with or without } \\
\text { symptoms (e.g., pruritus, } \\
\text { burning, tightness); } \\
\text { limiting instrumental } \\
\text { activities of daily living } \\
\text { (ADL); rash covering > } \\
30 \% \text { BSA with or without } \\
\text { mild symptoms }\end{array}$ & $\begin{array}{l}\text { 1st occurrence: Continue } \\
\text { treatment and consider } \\
\text { topical therapy for } \\
\text { symptomatic relief. If no } \\
\text { improvement within } 7 \\
\text { days, see below } \\
\text { No improvement, } 2 \text { nd } \\
\text { or 3rd occurrence: } \\
\text { Interrupt treatment until } \\
\text { toxicity resolves to Grade } \\
\text { 0-1. When resuming } \\
\text { treatment, decrease dose } \\
\text { by one dose level ( } 400 \\
\text { mg daily or } 400 \text { mg every } \\
\text { other day) } \\
\text { 4th occurrence: } \\
\text { Discontinue }\end{array}$ & $\begin{array}{l}\text { 1st occurrence: withhold } \\
\text { until improves to Grade } \\
0-1 \text { or baseline. Resume at } \\
8 \mathrm{mg} \text { if } \geq 60 \mathrm{~kg} \text {, } 4 \mathrm{mg} \text { if < } \\
60 \mathrm{~kg} \\
2 \mathrm{nd} \text { occurrence: withhold } \\
\text { until improves to Grade } \\
0-1 \text { or baseline. Resume } \\
\text { at } 4 \mathrm{mg} \text { if } \geq 60 \mathrm{~kg} \text {, } 4 \mathrm{mg} \\
\text { Q.O.D. if }<60 \mathrm{~kg} \\
\text { 3rd occurrence: Withhold } \\
\text { until improves to Grade } \\
\text { 0-1 or baseline. Resume } \\
\text { at } 4 \text { mg Q.O.D if } \geq 60 \mathrm{~kg} \text {, } \\
\text { discontinue }<60 \mathrm{~kg}\end{array}$ & $\begin{array}{l}\text { 1st occurrence: withhold } \\
\text { until improves to Grade } 1 \\
\text { or baseline. Resume at } 40 \\
\text { mg daily } \\
\text { 2nd occurrence: Withhold } \\
\text { until improves to Grade } 1 \\
\text { or baseline. Resume at } 20 \\
\text { mg daily } \\
\text { 3rd occurrence: withhold } \\
\text { until improves to Grade } \\
1 \text { or baseline. Resume at } \\
20 \text { mg daily if tolerated or } \\
\text { discontinue }\end{array}$ & $\begin{array}{l}\text { 1st occurence: Reduce } \\
\text { dose to } 120 \text { mg daily and } \\
\text { start supportive therapy. } \\
\text { If the toxicity does not } \\
\text { improve within } 7 \text { days } \\
\text { interrupt therapy until } \\
\text { the toxicity resolves or } \\
\text { improves to grade } 1 \text {. Then } \\
\text { can restart at } 120 \text { mg daily } \\
\text { 2nd occurrence: Interrupt } \\
\text { and institute supportive } \\
\text { measures until toxicity } \\
\text { resolves or improves to } \\
\text { grade } 1 \text {. Reduce dose to } \\
80 \text { mg daily } \\
\text { 3rd occurrence: } \\
\text { Discontinue if failure to } \\
\text { tolerate } 80 \text { mg daily dose }\end{array}$ \\
\hline
\end{tabular}


III: Macules/papules covering $>30 \%$ BSA with moderate or severe symptoms; limiting self care ADL 1st occurrence: Interrupt treatment until toxicity

resolves to Grade

$0-1$. When resuming

treatment, decrease dose

by one dose level (400

mg daily or 400 mg every

other day)

2nd occurrence: Interrupt

treatment until toxicity

resolves to Grade

$0-1$. When resuming

treatment, decrease dose

by one dose level (400

mg daily or 400 mg every

other day)

3rd occurrence:

Discontinue
Proceed the same as for grade II toxicity

1st occurrence: Interrupt treatment and start supportive measures. Interrupt until toxicity resolves or improves to grade 1. But treatment must be stopped for a minimum of 7 days. Resume dose at $120 \mathrm{mg}$ daily

2nd occurrence: Interrupt treatment and start supportive measures. Interrupted until toxicity resolves or improves to grade 1. Stop for a minimum of 7 days. Resume dose at $80 \mathrm{mg}$ daily 3rd occurrence: Discontinue

Table 3. Stomatitis and tyrosine kinase inhibitor treatment modifications

\begin{tabular}{|c|c|c|c|c|}
\hline \multirow{2}{*}{$\begin{array}{l}\text { Stomatitis } \\
\text { Grade }\end{array}$} & \multicolumn{4}{|c|}{ Tyrosine kinase inhibitor } \\
\hline & Sorafenib & Lenvatinib & Cabozantinib & Regorafenib \\
\hline $\begin{array}{l}\text { I: asymptomatic or mild } \\
\text { symptoms }\end{array}$ & \multicolumn{4}{|c|}{ No modification, use topical relief agents } \\
\hline $\begin{array}{l}\text { II: moderate pain or } \\
\text { ulcers that do not } \\
\text { interfere with oral intake }\end{array}$ & $\begin{array}{l}\text { 1st occurrence: Continue } \\
\text { treatment and consider } \\
\text { topical therapy for } \\
\text { symptomatic relief. If no } \\
\text { improvement within } 7 \\
\text { days, see below } \\
\text { No improvement, 2nd } \\
\text { or 3rd occurrence: } \\
\text { Interrupt treatment until } \\
\text { toxicity resolves to Grade } \\
\text { 0-1. When resuming } \\
\text { treatment, decrease dose } \\
\text { by one dose level (400 } \\
\text { mg daily or } 400 \text { mg every } \\
\text { other day) } \\
\text { 4th occurrence: } \\
\text { Discontinue }\end{array}$ & $\begin{array}{l}\text { 1st occurrence: withhold } \\
\text { until improves to Grade } \\
0-1 \text { or baseline. Resume at } \\
8 \mathrm{mg} \text { if } \geq 60 \mathrm{~kg}, 4 \mathrm{mg} \text { if < } \\
60 \mathrm{~kg} \\
2 \text { nd occurrence: withhold } \\
\text { until improves to Grade } \\
\text { 0-1 or baseline. Resume } \\
\text { at } 4 \mathrm{mg} \text { if } \geq 60 \mathrm{~kg} \text {, } 4 \mathrm{mg} \\
\text { Q.O.D. if }<60 \mathrm{~kg} \\
\text { 3rd occurrence: Withhold } \\
\text { until improves to Grade } \\
\text { 0-1 or baseline. Resume } \\
\text { at } 4 \text { mg Q.O.D if } \geq 60 \mathrm{~kg} \text {, } \\
\text { discontinue }<60 \mathrm{~kg}\end{array}$ & $\begin{array}{l}\text { 1st occurrence: withhold } \\
\text { until improves to Grade } 1 \\
\text { or baseline. Resume at } 40 \\
\text { mg daily } \\
\text { 2nd occurrence: Withhold } \\
\text { until improves to Grade } 1 \\
\text { or baseline. Resume at } 20 \\
\text { mg daily } \\
\text { 3rd occurrence: withhold } \\
\text { until improves to Grade } \\
1 \text { or baseline. Resume at } \\
20 \text { mg daily if tolerated or } \\
\text { discontinue }\end{array}$ & $\begin{array}{l}\text { 1st occurence: Reduce } \\
\text { dose to } 120 \text { mg daily and } \\
\text { start supportive therapy. } \\
\text { If the toxicity does not } \\
\text { improve within } 7 \text { days } \\
\text { interrupt therapy until } \\
\text { the toxicity resolves or } \\
\text { improves to grade } 1 \text {. Then } \\
\text { can restart at } 120 \text { mg daily } \\
\text { 2nd occurrence: Interrupt } \\
\text { and institute supportive } \\
\text { measures until toxicity } \\
\text { resolves or improves to } \\
\text { grade } 1 . \text { Reduce dose to } 80 \\
\text { mg daily } \\
\text { 3rd occurrence: } \\
\text { Discontinue if failure to } \\
\text { tolerate } 80 \text { mg daily dose }\end{array}$ \\
\hline $\begin{array}{l}\text { III: Severe pain } \\
\text { interfering with oral } \\
\text { intake }\end{array}$ & $\begin{array}{l}\text { 1st occurrence: Interrupt } \\
\text { treatment until toxicity } \\
\text { resolves to Grade } \\
0-1 \text {. When resuming } \\
\text { treatment, decrease dose } \\
\text { by one dose level (400 } \\
\text { mg daily or } 400 \text { mg every } \\
\text { other day) } \\
\text { 2nd occurrence: Interrupt } \\
\text { treatment until toxicity } \\
\text { resolves to Grade } \\
0-1 . \text { When resuming } \\
\text { treatment, decrease dose } \\
\text { by one dose level (400 } \\
\text { mg daily or } 400 \text { mg every } \\
\text { other day) } \\
\text { 3rd occurrence: } \\
\text { Discontinue }\end{array}$ & Proceed the same as for gr & ade II toxicity & $\begin{array}{l}\text { 1st occurrence: Interrupt } \\
\text { treatment and start } \\
\text { supportive measures. } \\
\text { Treatment must be } \\
\text { interrupted until toxicity } \\
\text { resolves or improves to } \\
\text { grade 1. But treatment } \\
\text { must be stopped for } \\
\text { a minimum of } 7 \text { days. } \\
\text { Resume dose at } 120 \text { mg } \\
\text { daily } \\
\text { 2nd occurrence: Interrupt } \\
\text { treatment and start } \\
\text { supportive measures. } \\
\text { Treatment must be } \\
\text { interrupted until toxicity } \\
\text { resolves or improves to } \\
\text { grade } 1 . \text { But treatment } \\
\text { must be stopped for } \\
\text { a minimum of } 7 \text { days. } \\
\text { Resume dose at } 80 \text { mg } \\
\text { daily } \\
\text { 3rd occurrence: } \\
\text { Discontinue }\end{array}$ \\
\hline
\end{tabular}




\section{The onset of cutaneous toxicity with Cabozantinib}

The onset of cutaneous toxicity with the use of Cabozantinib to treat HCC has not been described. However, the onset has been documented in the treatment of progressive urothelial carcinoma by Zuo et al. ${ }^{[15]}$ and in renal clear cell carcinoma by Choueiri et al. ${ }^{[54]}$ About half of the patients in each study treated with Cabozantinib developed HFRS with a median onset of 4-5 weeks. Additionally In the study by Zuo et al. ${ }^{[15]}$ skin changes, including xerosis and scrotal erythema, developed within approximately 5 weeks of Cabozantinib treatment.

\section{Dose reduction}

The starting dose of Cabozantinib is $60 \mathrm{mg}$ daily for the treatment of HCC. Dose reductions for skin toxicities are displayed in Tables 1,2 and $3^{[55]}$.

\section{REGORAFENIB}

\section{Regorafenib Cutaneous Toxicity and Toxicity Incidence}

Regorafenib is another TKI approved for second-line therapy of HCC. The RESORCE trial showed that in patients whose HCC progressed on Sorafenib, those subsequently treated with Regorafenib had improved median OS to 10.6 months (95\%CI: 9.1-12.1) compared to 7.8 months (95\%CI: 6.3-8.8) in those treated with placebo ${ }^{[5]}$. A follow up study also found that patients sequentially treated with Regorafenib after Sorafenib had improved OS from the start of Sorafenib treatment to death on study compared to placebo control. 26.0 months (95\%CI: 22.6-28.1) for Regorafenib and 19.2 months (95\%CI: 16.3-22.8) for placebo ${ }^{[56]}$.

In the RESORCE study, all patients receiving Regorafenib experienced an adverse event. Cutaneous toxicities related to Regorafenib and their incidences include HFRS (53\%, grade 3: 13\%) and stomatitis (13\% grade 3: $1 \%$ ). Of note, $2 \%$ of patients suffering from HFRS discontinued Regorafenib treatment ${ }^{[5]}$.

\section{The onset of cutaneous toxicity with Regorafenib}

Regorafenib induced HFRS occurs early in treatment with one study showing a median time to the first occurrence of 15 days ${ }^{[57]}$. Onset of stomatitis usually occurs between 5 and 14 days after treatment initiation ${ }^{[58]}$.

Monitoring of patients should occur frequently especially early in treatment. Patients should be seen at least every 1-2 weeks during the first two cycles and every 4-6 weeks thereafter ${ }^{[14,59-61]}$.

\section{Dose reduction}

The recommended starting dose of Regorafenib is $160 \mathrm{mg}$ daily for 21 days followed by 7 days of a dosing free interval to complete a 28 -day cycle. Treatment is continued until disease progression or unacceptable toxicity. Dose reductions with Regorafenib are seen in Tables 1, 2, and $3^{[62]}$.

The incidences of the most common cutaneous toxicities and their toxicity grade are summarized for each tyrosine kinase inhibitor in Table 4.

\section{ADVERSE EVENTS AND EFFICACY OF TKIS}

The relationship between patients experiencing adverse events and treatment efficacy has been noted by multiple investigators. In a study of 65 patients treated with Sorafenib, patients who developed at least grade 1 skin toxicity had tumor control rates of $48.3 \%$ versus $19.4 \%$ in patients who did not develop skin toxicity ${ }^{[63]}$. Another study of Sorafenib showed a positive association between higher-grade skin toxicity (> grade 2) and disease control when compared to patients who developed lower grade toxicity or had no skin toxicity ${ }^{[64]}$. An association was also seen with adverse events and overall survival in patients treated 
Table 4. Incidence of TKI induced cutaneous toxicities during HCC therapy

\begin{tabular}{llcc}
\hline Tyrosine kinase inhibitor & \multicolumn{1}{c}{ Cutaneous toxicity } & Incidence of grade 1 or 2 toxicity & Incidence of grade 3 toxicity \\
\hline Sorafenib & Hand foot reaction syndrome & $24 \%$ & $8 \%$ \\
& Rash & $16 \%$ & $1 \%$ \\
Levantinib & Alopecia & $14 \%$ & $0 \%$ \\
& Hand foot reaction syndrome & $27 \%$ & $3 \%$ \\
& Rash & $10 \%$ & $0 \%$ \\
Cabozantinib & Alopecia & $3 \%$ & $0 \%$ \\
& Hand foot reaction syndrome & $46 \%$ & $17 \%$ \\
Regorafenib & Rash & $12 \%$ & $<1 \%$ \\
& Stomatitis & $13 \%$ & $2 \%$ \\
& Hand foot reaction syndrome & $53 \%$ & $13 \%$ \\
\hline
\end{tabular}

TKI: tyrosine kinase inhibitor; HCC: hepatocellular carcinoma

Table 5. Recommendations for adverse event management

\begin{tabular}{|c|c|c|}
\hline \multirow{2}{*}{ Adverse event } & \multicolumn{2}{|c|}{ Recommended management strategies } \\
\hline & Prophylactic management & Adverse event management \\
\hline $\begin{array}{l}\text { Hand and foot reaction } \\
\text { syndrome }\end{array}$ & $\begin{array}{l}\text { Baseline full body skin examination } \\
\text { Removal of any pre-treatment hyperkeratotic skin } \\
\text { Consider use of prophylactic 20\% urea based cream } \\
\text { applied twice a day } \\
\text { Avoid tight footwear or gloves } \\
\text { Use of emollients liberally }\end{array}$ & $\begin{array}{l}\text { Topical } 20 \%-40 \% \text { urea creams applied to ares of } \\
\text { hyperkeratosis twice daily } \\
\text { Clobetasol } 0.05 \% \text { ointment applied to erythematous } \\
\text { areas twice daily } \\
\text { Topical } 2 \% \text { lidocaine cream for analgesia }\end{array}$ \\
\hline Rash & $\begin{array}{l}\text { Use perfume free soap } \\
\text { Loose comfortable clothing } \\
\text { Liberal use of moisturizers }\end{array}$ & $\begin{array}{l}\text { Corticosteroids } \\
\text { Antihistamines }\end{array}$ \\
\hline Scrotal eczema & Athletic supporter & $\begin{array}{l}\text { Zinc oxide and menthol barrier ointment } \\
\text { Topical corticosteroids }\end{array}$ \\
\hline Stomatitis & $\begin{array}{l}\text { Brush teeth after meals with soft toothbrush } \\
\text { Mouth rinses without alcohol } \\
\text { Avoid spicy foods, alcohol and tobacco }\end{array}$ & $\begin{array}{l}\text { Magic mouthwashes or oral rinses with } 0.9 \% \text { saline } \\
\text { Topical mucosal anesthetics }\end{array}$ \\
\hline Erythema multiforme & None & $\begin{array}{l}\text { Antihistamines } \\
\text { Topical corticosteroids } \\
\text { Systemic glucocorticoids }\end{array}$ \\
\hline Stevens johnson syndrome & None & $\begin{array}{l}\text { Transfer to intensive care unit or burn unit } \\
\text { Thermoregulation of body temperature to 28-32 } \\
\text { Celsius } \\
\text { Fluid replacement } \\
\text { Systemic corticosteroids } \\
\text { Antiseptic baths }\end{array}$ \\
\hline
\end{tabular}

with Lenvatinib ${ }^{[65]}$. Similar results were also noted for Cabozantinib with patients who experienced any grade HFRS having improved median overall survival and progression-free survival compared to those who did not develop HFRS ${ }^{[66]}$. The development of HFRS and rash was also associated with overall survival in patients treated with Regorafenib for metastatic colorectal cancer ${ }^{[67]}$. Although these associations have been documented with TKIs, a physiologic relationship has not been described. But it has been postulated that the association between cutaneous toxicity and treatment efficacy could be caused by variations in pharmacokinetics as both the toxicity and the response may be dose-dependent ${ }^{[65]}$. It has also been suggested that patients who develop skin toxicities may have tyrosine kinase polymorphisms that are more sensitive to drug inhibition which results in greater anti-tumor control but more skin toxicity ${ }^{[61]}$. More investigation is warranted but if treatment efficacy is dose-dependent then symptomatic relief of cutaneous toxicity is warranted to maintain medication compliance to achieve maximum results. However, if treatment efficacy is pre-determined by tyrosine kinase polymorphism then further genetic screening is warranted to determine who will benefit most from TKI therapy. 


\section{CONCLUSION}

Tyrosine kinase inhibitors have successfully extended the overall survival in patients with hepatocellular carcinoma ${ }^{[4-7]}$. However these treatments have been noted to cause severe side effects including liver toxicity, hypertension, gastrointestinal toxicity and the discussed cutaneous toxicities ${ }^{[68]}$. These cutaneous toxicities tend to occur during the first and second months of treatment and can be managed with symptomatic treatment and dose reductions if necessary. Additional prophylactic measures can help prevent the manifestation of the some of most common cutaneous toxicities including HFRS and stomatitis. It is in these authors' opinions on and others that the monitoring of TKI treated patients for cutaneous toxicities should be conducted every 2 weeks for the first few months of treatment and a baseline dermatological exam is also necessary ${ }^{[22,58,68]}$. A summary of recommendations for the management of cutaneous adverse events are displayed in Table 5. As cutaneous toxicities have also been seen with more recently developed TKIs, including Afatinib and Dorafenib, it appears as more TKIs are used to treat HCC that these cutaneous toxicities will remain as treatment side effects requiring careful management ${ }^{[69,70]}$.

\section{DECLARATIONS}

\section{Authors' contributions}

Made substantial contributions to conception and design of the review article: Silk T, Wu J

\section{Availability of data and materials}

Not applicable.

\section{Financial support and sponsorship}

None.

\section{Conflicts of interest}

All authors declared that there are no conflicts of interest.

\section{Ethical approval and consent to participate}

Not applicable.

\section{Consent for publication}

Not applicable.

\section{Copyright}

(c) The Author(s) 2020.

\section{REFERENCES}

1. Bray F, Ferlay J, Soerjomataram I, Siegel RL, Torre LA, et al. Global cancer statistics 2018: GLOBOCAN estimates of incidence and mortality worldwide for 36 cancers in 185 countries. CA Cancer J Clin 2018;68:394-424.

2. Villanueva A. Hepatocellular carcinoma. N Engl J Med 2019;380:1450-62.

3. Llovet JM, Montal R, Sia D, Finn RS. Molecular therapies and precision medicine for hepatocellular carcinoma. Nat Rev Clin Oncol 2018;15:599-616.

4. Llovet JM, Ricci S, Mazzaferro V, Hilgard P, Gane E, et al; SHARP Investigators Study Group. Sorafenib in advanced hepatocellular carcinoma. N Engl J Med 2008;359:378-90.

5. Bruix J, Qin S, Merle P, Granito A, Huang Y, et al. Regorafenib for patients with hepatocellular carcinoma who progressed on sorafenib treatment (RESORCE): a randomised, double-blind, placebo-controlled, phase 3 trial. Lancet 2017;389:56-66.

6. Abou-Alfa GK, Meyer T, Cheng AL, El-Khoueiry AB, Rimassa L, et al. Cabozantinib in patients with advanced and progressing hepatocellular carcinoma. N Engl J Med 2018;379:54-63.

7. Kudo M, Finn RS, Qin S, Han K, Ikeda K, et al. Lenvatinib versus sorafenib in first-line treatment of patients with unresectable hepatocellular carcinoma: a randomised phase 3 non-inferiority trial. Lancet 2018;391:1163-73.

8. Reyes-Habito CM, Roh EK. Cutaneous reactions to chemotherapeutic drugs and targeted therapy for cancer: Part II. Targeted therapy. J 
Am Acad Dermatol 2014;71:217.e1-11; quiz 227-8.

9. Chu D, Lacouture ME, Fillos T, Wu S. Risk of hand-foot skin reaction with sorafenib: a systematic review and meta-analysis. Acta Oncol 2008;47:176-86.

10. Dranitsaris G, Vincent MD, Yu J, Huang L, Fang F, et al. Development and validation of a prediction index for hand-foot skin reaction in cancer patients receiving sorafenib. Ann Oncol 2012;23:2103-8.

11. Cheng A, Kang Y, Chen Z, Tsao C, Qin S, et al. Efficacy and safety of sorafenib in patients in the Asia-Pacific region with advanced hepatocellular carcinoma: a phase III randomised, double-blind, placebo-controlled trial. Lancet Oncol 2009;10:25-34.

12. Zhang HL, Qin XJ, Wang HK, Gu WJ, Ma CG, et al. Clinicopathological and prognostic factors for long-term survival in Chinese patients with metastatic renal cell carcinoma treated with sorafenib: a single-center retrospective study. Oncotarget 2015;6:36870-83.

13. Lipworth AD, Robert C, Zhu AX. Hand-foot syndrome (hand-foot skin reaction, palmar-plantar erythrodysesthesia): focus on sorafenib and sunitinib. Oncology 2009;77:257-71.

14. McLellan B, Ciardiello F, Lacouture ME, Segaert S, Van Cutsem E. Regorafenib-associated hand-foot skin reaction: practical advice on diagnosis, prevention, and management. Ann Oncol 2015;26:2017-26.

15. Zuo RC, Apolo AB, DiGiovanna JJ, Parnes HL, Keen CM, et al. Cutaneous adverse effects associated with the tyrosine-kinase inhibitor cabozantinib. JAMA Dermatol 2015;151:170-7.

16. Reed N, Glen H, Gerrard G, Good J, Lei M, et al. Expert consensus on the management of adverse events during treatment with lenvatinib for thyroid cancer. Clin Oncol (R Coll Radiol) 2020;32:e145-53.

17. Jacobi U, Waibler E, Schulze P, Sehouli J, Oskay-Ozcelik G, et al. Release of doxorubicin in sweat: first step to induce the palmar-plantar erythrodysesthesia syndrome? Ann Oncol 2005;16:1210-1.

18. Lacouture ME, Wu S, Robert C, Atkins MB, Kong HH, et al. Evolving strategies for the management of hand-foot skin reaction associated with the multitargeted kinase inhibitors sorafenib and sunitinib. Oncologist 2008;13:1001-11.

19. Ai L, Xu Z, Yang B, He Q, Luo P. Sorafenib-associated hand-foot skin reaction: practical advice on diagnosis, mechanism, prevention, and management. Expert Rev Clin Pharmacol 2019;12:1121-7.

20. Anderson R, Jatoi A, Robert C, Wood LS, Keating KN, et al. Search for evidence-based approaches for the prevention and palliation of hand-foot skin reaction (HFSR) caused by the multikinase inhibitors (MKIs). Oncologist 2009;14:291-302.

21. Ren Z, Zhu K, Kang H, Lu M, Qu Z, et al. Randomized controlled trial of the prophylactic effect of urea-based cream on sorafenibassociated hand-foot skin reactions in patients with advanced hepatocellular carcinoma. J Clin Oncol 2015;33:894-900.

22. Brose MS, Frenette CT, Keefe SM, Stein SM. Management of sorafenib-related adverse events: a clinician's perspective. Semin Oncol 2014;41 Suppl 2:S1-16.

23. Common Terminology Criteria for Adverse Events (CTCAE) v5. US Department of health and human services. National Institute of Health. 2017. Available from: https://ctep.cancer.gov/protocoldevelopment/electronic_applications/docs/CTCAE_v5_Quick_ Reference_5x7.pdf. [Last accessed on 30 Sep 2020]

24. Vukelja SJ, Lombardo FA, James WD, Weiss RB. Pyridoxine for the palmar-plantar erythrodysesthesia syndrome. Ann Intern Med 1989;111:688-9.

25. Lacouture ME, Reilly LM, Gerami P, Guitart J. Hand foot skin reaction in cancer patients treated with the multikinase inhibitors sorafenib and sunitinib. Ann Oncol 2008;19:1955-61.

26. Autier J, Escudier B, Wechsler J, Spatz A, Robert C. Prospective study of the cutaneous adverse effects of sorafenib, a novel multikinase inhibitor. Arch Dermatol 2008;144:886-92.

27. Lee WJ, Lee JL, Chang SE, Lee MW, Kang YK, et al. Cutaneous adverse effects in patients treated with the multitargeted kinase inhibitors sorafenib and sunitinib. Br J Dermatol 2009;161:1045-51.

28. Haddad RI, Schlumberger M, Wirth LJ, Sherman EJ, Shah MH, et al. Incidence and timing of common adverse events in Lenvatinibtreated patients from the SELECT trial and their association with survival outcomes. Endocrine 2017;56:121-8.

29. Wood LS. Managing the side effects of sorafenib and sunitinib. Commun Oncol 2006;3:558-62.

30. Pérez-Soler R, Delord JP, Halpern A, Kelly K, Krueger J, et al. HER1/EGFR inhibitor-associated rash: future directions for management and investigation outcomes from the HER1/EGFR inhibitor rash management forum. Oncologist 2005;10:345-56.

31. Sarkodie T, Ross P. Late presentation of sorafenib-associated rash: a case report. J Med Case Rep 2010;4:338.

32. Çalışkan S. Sorafenib-induced Scrotal Eczema. Rev Urol 2015;17:250-1.

33. Ishak RS, Aad SA, Kyei A, Farhat FS. Cutaneous manifestations of anti-angiogenic therapy in oncology: review with focus on VEGF inhibitors. Crit Rev Oncol Hematol 2014;90:152-64.

34. De Wit M, Boers-Doets CB, Saettini A, Vermeersch K, de Juan CR, et al. Prevention and management of adverse events related to regorafenib. Support Care Cancer 2014;22:837-46.

35. Harris DJ, Eilers J, Harriman A, Cashavelly BJ, Maxwell C. Putting evidence into practice: evidence-based interventions for the management of oral mucositis. Clin J Oncol Nurs 2008;12:141-52.

36. Bensinger W, Schubert M, Ang KK, Brizel D, Brown E, et al; NCCN Task Force Report. Prevention and management of mucositis in cancer care. J Natl Compr Canc Netw 2008;6 Suppl 1:S1-21.

37. Califano R, Tariq N, Compton S, Fitzgerald DA, Harwood CA, et al. Expert consensus on the management of adverse events from EGFR tyrosine kinase inhibitors in the UK. Drugs 2015;75:1335-48.

38. Bayer HealthCare Pharmaceuticals Inc. Nexavar (Sorafenib) [package insert]. U.S. Food and Drug Administration website. Available from: https://www.accessdata.fda.gov/drugsatfda_docs/label/2018/021923s020lbl.pdf. [Last accessed on 24 Sep 2017]

39. Guggina LM, Choi AW, Choi JN. EGFR inhibitors and cutaneous complications: a practical approach to management. Oncol Ther 
2017;5:135-48.

40. Sohn KH, Oh SY, Lim KW, Kim MY, Lee SY, et al. Sorafenib induces delayed-onset cutaneous hypersensitivity: a case series. Allergy Asthma Immunol Res 2015;7:304-7.

41. Mantovani A, Álvares-Da-Silva MR. Anaphylaxis preceded by erythema multiforme with sorafenib: first case report. Ann Hepatol 2019;18:777-9.

42. Trayes KP, Love G, Studdiford JS. Erythema multiforme: recognition and management. Am Fam Physician 2019;100:82-88.

43. Ayangco L, Rogers RS. Oral manifestations of erythema multiforme. Dermatol Clin 2003;21:195-205.

44. Sokumbi O, Wetter DA. Clinical features, diagnosis, and treatment of erythema multiforme: a review for the practicing dermatologist. Int J Dermatol 2012;51:889-902.

45. Choi MK, Woo HY, Heo J, Cho M, Kim GH, et al. Toxic epidermal necrolysis associated with sorafenib and tosufloxacin in a patient with hepatocellular carcinoma. Ann Dermatol 2011;23:S404-7.

46. Dodiuk-Gad RP, Chung WH, Valeyrie-Allanore L, Shear NH. Stevens-johnson syndrome and toxic epidermal necrolysis: an update. Am J Clin Dermatol 2015;16:475-93.

47. Duong TA, Valeyrie-allanore L, Wolkenstein P, Chosidow O. Severe cutaneous adverse reactions to drugs. Lancet 2017;390:1996-2011.

48. Kardaun SH, Jonkman MF. Dexamethasone pulse therapy for Stevens-Johnson syndrome/toxic epidermal necrolysis. Acta Derm Venereol 2007;87:144-8.

49. Valeyrie-Allanore L, Wolkenstein P, Brochard L, Ortonne N, Maître B, et al. Open trial of ciclosporin treatment for Stevens-Johnson syndrome and toxic epidermal necrolysis. Br J Dermatol 2010;163:847-53.

50. Paradisi A, Abeni D, Bergamo F, Ricci F, Didona D, et al. Etanercept therapy for toxic epidermal necrolysis. J Am Acad Dermatol 2014;71:278-83.

51. Kannaiyan R, Mahadevan D. A comprehensive review of protein kinase inhibitors for cancer therapy. Expert Rev Anticancer Ther 2018;18:1249-70.

52. Autier J, Mateus C, Wechsler J, Spatz A, Robert C. Cutaneous side effects of sorafenib and sunitinib. Ann Dermatol Venereol 2008;135:148-53; quiz 147, 154

53. Eisai Inc. Lenvima (Lenvatinib) [package insert]. U.S. Food and Drug Administration website. Available from: https://www.accessdata. fda.gov/drugsatfda_docs/label/2018/206947s007lbl.pdf. [Last accessed on 24 Sep 2020]

54. Choueiri TK, Escudier B, Powles T, Tannir NM, Mainwaring PN, et al. Cabozantinib versus everolimus in advanced renal cell carcinoma (METEOR): final results from a randomised, open-label, phase 3 trial. Lancet Oncol 2016;17:917-27.

55. Exelixis. Cabometyx (Cabozantinib) [package insert]. U.S. Food and Drug Administration website. Available from: https://www. accessdata.fda.gov/drugsatfda_docs/label/2019/208692s003lbl.pdf. [Last accessed on 24 Sep 2020]

56. Finn RS, Merle P, Granito A, Huang YH, Bodoky G, et al. Outcomes of sequential treatment with sorafenib followed by regorafenib for HCC: additional analyses from the phase III RESORCE trial. J Hepatol 2018;69:353-8.

57. Grothey A, Sobrero AF, Siena S, Falcone A, Ychou M, et al. Time profile of adverse events (AEs) from regorafenib (REG) treatment for metastatic colorectal cancer (mCRC) in the phase III CORRECT study. Available from: https://doi.org/10.1200/jco.2013.31.15 suppl.3637. [Last accessed on 30 Sep 2020]

58. Sastre J, Argilés G, Benavides M, Feliú J, García-Alfonso P, et al. Clinical management of regorafenib in the treatment of patients with advanced colorectal cancer. Clin Transl Oncol 2014;16:942-53.

59. Khan G, Moss RA, Braiteh F, Saltzman M. Proactive strategies for regorafenib in metastatic colorectal cancer: implications for optimal patient management. Cancer Manag Res 2014;6:93-103.

60. Grothey A, George S, van Cutsem E, Blay JY, Sobrero A, et al. Optimizing treatment outcomes with regorafenib: personalized dosing and other strategies to support patient care. Oncologist 2014;19:669-80.

61. Mitchell J, Khoukaz T, McNeal D, Brent L. Adverse event management strategies: optimizing treatment with regorafenib in patients with metastatic colorectal cancer. Clin J Oncol Nurs 2014;18:E19-25.

62. Bayer HealthCare Pharmaceuticals Inc. Stivarga (Regorafenib). U.S. Food and Drug Administration website. Available from: https:// www.accessdata.fda.gov/drugsatfda_docs/label/2013/204369lbl.pdf. [Last accessed on 24 Sep 2020]

63. Vincenzi B, Santini D, Russo A, Addeo R, Giuliani F, et al. Early skin toxicity as a predictive factor for tumor control in hepatocellular carcinoma patients treated with sorafenib. Oncologist 2010;15:85-92.

64. Shomura M, Kagawa T, Shiraishi K, Hirose S, Arase Y, et al. Skin toxicity predicts efficacy to sorafenib in patients with advanced hepatocellular carcinoma. World J Hepatol 2014;6:670-6.

65. Sung MW, Finn RS, Qin S, Han K, Ikeda K, et al. Association between overall survival and adverse events with lenvatinib treatment in patients with hepatocellular carcinoma (REFLECT). JCO 2019;37:317.

66. Abou-alfa GK, Meyer T, Cheng A, Cicin I, Bolondi L, et al. Association of adverse events (AEs) with efficacy outcomes for cabozantinib (C) in patients (pts) with advanced hepatocellular carcinoma (aHCC) in the phase III CELESTIAL trial. JCO 2019;37:4088.

67. Wakatsuki T, Shinozaki E, Suenaga M, Nakayama I, Matsushima T, et al. Associations between regorafenib-induced adverse events (AEs) and efficacy in metastatic colorectal cancer (mCRC). JCO 2017;35:556.

68. Rimassa L, Danesi R, Pressiani T, Merle P. Management of adverse events associated with tyrosine kinase inhibitors: Improving outcomes for patients with hepatocellular carcinoma. Cancer Treat Rev 2019;77:20-8.

69. Kong Y, Sun L, Hou Z, Zhang Y, Chen P, et al. Apatinib is effective for treatment of advanced hepatocellular carcinoma. Oncotarget 2017;8:105596-605.

70. Liu J, Li X, Zhang H, Chen G, Chen H, et al. Safety, pharmacokinetics and efficacy of donafenib in treating advanced hepatocellular carcinoma: report from a phase $1 \mathrm{~b}$ trial. Pharmazie 2019;74:688-93. 